CORRECTION

https://doi.org/10.1038/s41586-018-0295-8

\title{
Author Correction: Genome-wide changes in lncRNA, splicing, and regional gene expression patterns in autism
}

Neelroop N. Parikshak, Vivek Swarup, T. Grant Belgard, Manuel Irimia, Gokul Ramaswami, Michael J. Gandal, Christopher Hartl, Virpi Leppa, Luis de la Torre Ubieta, Jerry Huang, Jennifer K. Lowe, Benjamin J. Blencowe, Steve Horvath \& Daniel H. Geschwind

Correction to: Nature https://doi.org/10.1038/nature20612, published online 05 December 2016.

In the Supplementary Information of this Letter, the labels for splicing events A3SS and A5SS were swapped in column D of Supplementary Table $3 \mathrm{a}$ and $\mathrm{b}$. Supplementary Table 3 has been corrected online. 